\title{
The Effect of Professional Development on Multilingual Education in Early Childhood in Luxembourg
}

\author{
Claudine Kirsch ${ }^{1} \&$ Gabrijela Aleksić ${ }^{1}$ \\ ${ }^{1}$ University of Luxembourg, Luxembourg \\ Correspondence: Claudine Kirsch, Department of Language and Literature, Humanities, Arts and Education, University \\ of Luxembourg, Esch-Belval, 11 Porte des Sciences, 4366 Esch-Alzette, Luxembourg.
}

Received: September 19, 2018 Accepted: October 16, 2018 Online Published: November 7, 2018

doi:10.5539/res.v10n4p148

URL: https://doi.org/10.5539/res.v10n4p148

\begin{abstract}
While multilingual programmes have been implemented in early childhood education in several countries, professionals have shown to be unsure of how to deal with language diversity and promote home languages. Therefore, there is a need for professional development. The present article discusses the outcomes of a professional course on multilingual education in early childhood delivered to 46 early-years practitioners in Luxembourg. Using a questionnaire administered prior to and after the course as well as interviews, we examined the influence of the training on attitudes to multilingual education and activities to develop Luxembourgish and home languages. The analysis drew on content analysis, paired samples $t$-test and correlational analysis. The findings show that the course positively influenced the professionals' knowledge about multilingualism and language learning, their attitudes towards home languages, their interest in organising activities in the children's home languages and the implementation of these activities. The results shed light on special interest areas such as the quality of input that future professional development courses could focus on.
\end{abstract}

Keywords: attitudes, early childhood, home languages, learning activities, Luxembourg, multilingual education

\section{Introduction}

In our globalised world where the heterogeneity of school populations is on the rise, there is an urgent need for multilingual pedagogies. Inclusive multilingual programmes place the learner at the centre and create spaces for dynamic language use. Because they value home languages and familiarize children with several languages and cultures, they benefit both monolinguals and bilinguals. Such programmes improve children's chances of school success and employability (Grin, 2003) and are in line with the UN convention on the rights of children which request the respect of the children's language, culture and values (United Nations, 1987, article 29).

There is a gap to be bridged between the identified need for multilingual education and effective practices in Early Childhood Education and Care (ECEC), a rapidly growing sector. Several studies demonstrated that the focus of officially multilingual programmes in ECEC is the development of the majority language and that home languages are rarely used (Kratzmann, Jahreiß, Frank, Ertanir, \& Sachse, 2017; Neumann, Kuhn, Tinguely, \& Brandenberg, 2017; Panagiotopoulou, 2016). This finding can partly be explained by the language ideologies operating at macro and micro levels, and the practitioners' beliefs, attitudes, skills and past practices. While some researchers reported that practitioners are unsure of how to deal with diversity and develop home languages (Gogolin et al., 2011), others emphasised the practitioners' weak understanding of bilingualism and language development, and revealed inadequate observation, planning and assessment skills (Stitzinger \& Lüdtke, 2014; Thoma \& Tracy, 2012).

Given the relationship between the quality in ECEC and the quality of the workforce (Deutsches Jugendinstitut [DJI], 2011; Waters \& Payler, 2015), and given the diversity of the workforce, practitioners should be offered professional development (thereafter PD) to achieve and sustain quality in ECEC. PD can be defined as a systematic effort to ensure that practitioners are adequately qualified when working with children and parents, and to provide them with opportunities to enhance their professional learning (Egert, 2015; King, 2014). Studies have shown that PD can contribute to the development of knowledge and skills and to shaping beliefs and practices (Egert, Fukkink, and Eckhardt, 2018; Kratzman et al. 2017; Ottley et al., 2016). While courses are on offer in the field of language and literacy development, few focus on bilingualism or multilingualism, and fewer still have been evaluated, a handful in Europe (Egert et al. 2018; Redder et al., 2011).

The present article is based in trilingual Luxembourg where multilingual education became mandatory in formal and 
non-formal ECEC institutions in autumn 2017. Teachers and carers are required to develop Luxembourgish, familiarize children with French and value their home languages. The language diversity of children continued to rise. In the academic year 2016/7, 38\% of the three-year olds spoke Luxembourgish at home, 22\% Portuguese and 40\% 'other' languages such as French or Albanian (MENJE, 2018). This article discusses some specific outcomes of a 15-hour-long professional development course on multilingual education delivered to 46 early-years practitioners in 2016. Our aim is to examine how professional development has shaped the practitioners' attitudes towards multilingual education and the activities implemented to develop Luxembourgish and home languages. The results from our questionnaire and interviews shed light on the course's potential to influence beliefs and practices and highlight special interest areas that future courses could profitably focus on.

Before presenting the outcomes, we discuss research findings on professional development and multilingual education, describe the language situation in Luxembourg, and outline the methodology.

\section{Professional Development, Beliefs and Practices}

The following sections will present relevant findings on the effects of PD on attitudes, knowledge and practices, and discuss beliefs on multilingualism as well as relevant multilingual practices.

\subsection{Theoretical Models and Effectiveness of Professional Development}

Theoretical models of PD hold that training can influence the practitioners' attitudes, knowledge and skills and the quality of their teaching. Some scholars hold that these changes in teacher outcomes and practices subsequently improve student learning (Desimone, Smith, \& Philips, 2013). This sequential model is based on the understanding that knowledge and beliefs mediate behaviour. However, from a theoretical point of view, it is also possible to envisage a different way of changing practice. Based on Bandura's (1986) social learning theory and on the concept of 'teacher noticing' (Star \& Strickland, 2008), practitioners may change their behaviour through observing others, identifying relevant strategies, and imitating these. This explains why some researchers, among them Hamre, Pianta, Burchinal et al. (2012) or Simon \& Sachse (2013), showed teachers video-recordings of interaction strategies and trained the participants to identify effective techniques. Seen from this perspective, practitioners may change their practice, which, in turn, enables them to change beliefs. Support comes from a study by Levin and Wadmany (2006) who found that the actual experience of using educational technologies together with the meetings with the research team contributed to changing the practitioners' beliefs related to ICT. These two pathways to changing a practice illustrate the complex relationships between beliefs, knowledge and practice (Pajares, 1992).

There are only a few empirical studies that demonstrate effects of PD on teacher outcomes, practices as well as child development (Egert et al., 2018; Werner, Linting, Vermeer, and van IJzendoorn, 2016). For instance, some researchers demonstrated positive outcomes of their PD on teacher beliefs (King, 2014; Ottley et al., 2015) and practices (Kratzmann et al., 2017; Sachse et al., 2016). In Germany, Stitzinger and Lüdtke (2014) reported that their training helped staff, particularly bilingual staff, improve their knowledge and skills in assessing children's language competences and diagnose language problems. Examining the influence of their PD in the domain of language and literacy in the United States, Hamre et al. (2012) found that their 14-week course had a significant effect on beliefs and knowledge. For instance, compared to the control group, the early childhood teachers in the experimental group reported stronger beliefs about the relevance of taking an active role in teaching, demonstrated more knowledge of interactional strategies and were more skilled in identifying effective teacher-child interactions in videos. Although these teachers also provided more effective emotional and instructional interactions than the control group, the researchers reported a modest effect of the PD on teacher-child interactions (practice). Other studies indicated positive effects of PD both on practices and child development. Examples from effective interaction training on language-modelling and language-promoting strategies (e.g. questions, expansion, corrective feedback, encouragement of peer interaction) come from the USA (e.g. Girolametto et al., 2012) and Germany (e.g. Buschmann and Sachse, 2018; Simon \& Sachse, 2013). These studies revealed that the professionals used more conversational strategies after the training and that the participating children who all had a language delay, talked more, more frequently and in more varied ways. The German team also tested the effectiveness of the interaction training on bilingual children. The preliminary results indicate that the teachers changed their language behaviour and that the children improved their competences in German (Sachse, Schuler \& Budde-Spengler, 2016).

Several meta-analyses provide further evidence of the effects of PD in ECEC on teacher outcomes, practices and child development (see Egert et al. (2018); Markussen-Brown, Juhl, Piasta, Bleses, Hojen, and Justice (2017) and Werner et al. (2016) for details). While these studies generally indicate positive effects of PD, the effect size differs. It is important to note that these analyses only take account of quantitative studies and have mostly been carried out in the United States. Thirty-eight of 48 studies discussed in Egert (2015) and 34 of 36 studies in Egert et al. (2018) were based in the US. The other studies came mainly from Canada with only five from Europe (Egert, 2015). Furthermore, Buschmann and Sachse (2018) report that studies on PD tend to focus on children with language delay and that those on multilingualism are rare. 
For instance, only one study in Egert (2015) focused on multilingualism (i.e. Simon \& Sachse, 2013). The present article addresses these gaps by examining the effects of PD on multilingual education in a quantitative and qualitative study.

While the previous paragraphs examined theoretical models of PD and highlighted some influential studies, the following one focuses on the conditions under which PD is likely to be effective. Researchers have shown that PD effectiveness is related to training that is collaborative, involves more than one person of the same institution, is medium or long-term (45 to 60 hours) and offers opportunities for active learning and transfer (Gogolin et al., 2011; Egert, 2015; Prenger, Poortman, \& Handelzalts, 2017). Trainers focus ideally on a specific content such as interaction strategies which they teach through a range of methods before they ask the practitioners to implement these and document their use (Egert, 2015; Egert et al., 2018). The documentation allows the practitioners to reflect on their practice and the trainers to support and give feedback (Gaikhorst, Beishuizen, Zijlstra \& Volman, 2017). Particularly promising are models where practitioners research their own practice collaboratively with an intent to change it, for example through action-research or in professional learning communities (Gaikhorst et al., 2017; Grierson \& Woloshyn, 2013; Trodd \& Dickerson, 2018). Enquiry-based models facilitate learning and change because, firstly, they are based on personal needs and provide practitioners with some control over their learning, which, in turn, makes it meaningful and relevant. Secondly, the methods encourage practitioners to collaboratively analyse their beliefs and construct new knowledge, thereby establishing links between theory and practice. Learning is likely to be sustainable because the practitioners develop a culture of learning and establish relationships with other actors to solve their locally situated problem (Gaikhorst et al., 2017; Prenger et al., 2017). Programmes that involve both teachers and carers can be effective. Kirsch (2015) found that the teachers and carers who took part in her team's training valued the collaboration and developed a better understanding of both professions, which helped to flatten professional hierarchies. However, there are few courses that bring together both professions owing in part to structural problems such as time and money (Gogolin et al., 2011). The present study brings together teachers and carers and analyses the influences of an enquiry-based PD on multilingual education on the practitioners' attitudes, knowledge and practices. Before presenting our study, we will briefly examine relevant studies on beliefs related to multilingualism and multilingual practices.

\subsection{Beliefs Related to Multilingualism and Language Learning Practices}

We define teacher beliefs as "a tacit set of often unconsciously held assumptions regarding educational issues and processes such as teaching learning, curriculum, schooling, and knowledge" (Levin \& Wadmany, 2006, p. 159). This concept, which includes attitudes, knowledge and values, has been a focus of many research studies because beliefs influence pedagogical practices and affect learning processes and academic achievement (Xu, 2012). Beliefs are influenced by biographical factors such as the family and cultural background, experiences of using and learning languages (Abreu, 2015) and the overall context such as location and educational polices (Li \& Walsh, 2011). In addition, they are informed by personality related factors such as age, gender, self-esteem or identity (Bernat \& Gvozdenko, 2005; Pajares, 1992) and by pedagogical practices and working experiences (Basöz \& Çubukçu, 2014; Levin and Wadmany, 2006). The range of influential factors helps explain why beliefs are difficult to change and why studies on the effect of teacher education on changing beliefs are inconclusive (Portolés \& Martí, 2018).

The majority of studies on teacher beliefs has been carried out with secondary teachers or pre-service teachers and only one involved pre-service primary teachers in trilingual contexts (see Portolés \& Martí, 2018). Although these studies examined the influence of teacher education rather than PD on beliefs, some relevant findings are mentioned next. Studies showed that teachers generally held positive beliefs on multilingualism but their practices were nevertheless grounded in commonly held monolingual beliefs such as the relevance of language separation and the idealization of the native speaker. Working with prospective pre-school and primary teachers in Valencia, Portolés \& Martí (2018) found that these, unlike teachers in other studies, disagreed with language separation models based on their understanding that learning several languages simultaneously is not harmful. However, while the prospective teachers promoted the development of multiple languages, they nevertheless had a clear preference for high status languages rather than minority languages.

Several recent studies in Europe examined the beliefs of early childhood practitioners and their language behaviour. Researchers reported generally positive views on both multilingualism and the use of minority languages in educational institutions (Fried et al., 2013; Kratzmann et al., 2017). In Germany, for example, 58\% of the practitioners surveyed agreed that the home language is relevant for the development of German (Viernickel, Nentwig-Gesemann, Nicolai, Schwarz, \& Zenker, 2013) and more than 90\% confirmed that bilingual children should be able to communicate in their home language (Kratzmann et al., 2013). Nevertheless, only $40 \%$ of practitioners sang or let children hear songs in their home language; $53 \%$ never or rarely drew on home languages, for instance to greet people, and $76 \%$ rarely or never used bilingual books (Viernickel et al., 2013). The trend is similar in multilingual contexts. In Austria, 63\% of the staff in multilingual crèches indicated that the children should be allowed to use their home language but only few actively promoted multilingualism (Datler, de Cillia, Garnitschnig, Sobzak, \& Zell, 2013). In Luxembourg, most of the practitioners in the éducation précoce approved of giving children opportunities to express themselves in their home 
language (Ministry of National Education, Childhood and Youth [MENJE] \& Integrative Research Unit on Social and Individual Development [INSIDE], 2015). However, only 25\% of the professionals indicated telling stories and $23 \%$ singing songs and chanting rhymes in home languages. By contrast, $77 \%$ of them used stories and $60 \%$ songs and rhymes in Luxembourgish. In most countries, multilingualism is tolerated at the best of times but not actively promoted (Kratzmann et al., 2017; Neumann et al., 2017).

According to Lengyel (2012) bilingual children learn early on to separate languages based on the belief that language separation is necessary for language acquisition. A strict separation creates a state of 'parallel monolingualism' (Heller, 2006) which clashes with the daily lives of these emergent multilinguals and can be detrimental to the development of their language development and identity (Cummins, 1996). In addition, it goes counter the dynamic views of multilingualism of the $21^{\text {st }}$ century that hold that all languages are permanently activated in our brain. 'Translanguaging', the use of one's entire linguistic and non-linguistic repertoire to communicate, is a normal practice in bilinguals and should be a legitimate one at school as well (García \& Li Wei, 2014; García \& Seltzer, 2016). It seems, therefore, unnecessary and counterproductive to call for monolingualizing structures in educational institutions. Familiarising practitioners with dynamic views of multilingualism in PD and making them aware of the 'monolingual habitus' (Gogolin, 1994) that govern practices in ECEC settings may help them reflect on their beliefs regarding multilingualism and reconsider these.

A final word addresses the language learning activities mentioned previously. Scholars in applied linguistics agree that playful, action-oriented, contextualised and child-centred activities offer opportunities for language learning because they provide input in one or several languages and encourage interactions. They also hold that early literacy practices contribute to language learning such as reading, telling and discussing stories, and using rhymes and songs (De Houwer, 2009; List, 2010). This understanding of effective practices seems to be shared by practitioners in Germany and Luxembourg (MENJE \& INSIDE, 2015; Viernickel et al., 2013) and in the United States (Burgess, Lundgren, Lloyd \& Pianta, 2001; Hindman \& Wasik, 2008). However, as said before, there is currently little evidence of multilingual practices.

In sum, this literature review has shown that, in general, early years practitioners have a favourable view of multilingualism and the use of the children's home languages but find it challenging to draw on the children's multilingual resources and develop several languages. There is a need for professional development on multilingual education because it can influence attitudes, beliefs, skills and practices although the relationship between these concepts remains complex.

\section{Early Childhood Education in Multilingual Luxembourg}

Luxembourg, a trilingual state in the centre of Europe, is known for having the highest immigration rates in Europe. The percentage of non-Luxembourgish nationals increased from 26\% in 1981 to $48 \%$ in 2018. Most non-nationals are Portuguese, French and Italian (National Institute of Statistics and Economic Studies of the Grand Duchy of Luxembourg [STATEC], 2018). As seen before, 62\% of three-year olds do not speak Luxembourgish at home (MENJE, 2018). The linguistic and cultural diversity of the population is reflected in the residents' daily language use. Neumann (2015) describes the language situation as one of 'linguistic superdiversity', whereby the choice of language depends on the interlocutor, the situation and the private or public domain. 'Translanguaging' is an everyday reality (Kirsch, 2017).

\subsection{Language Ideologies and Language Policies in ECEC in Luxembourg}

Analysing the language ideologies in Luxembourg, Horner and Weber (2008) hold that there is a complex relationship between Luxembourgish and multilingualism. On the one hand, Luxembourgish is being construed as a marker of national identity and as the means of ensuring social integration and, on the other, multilingualism is perceived as the unique characteristic of Luxembourg and as the bearer of economic and cultural benefits. These ideologies influence language policies. In the past 20 years, the ECEC sector has been subjected to several policy changes. This sector includes both formal education (the éducation précoce for three-year-olds and the two-year compulsory preschool for four-year-olds) and the non-formal education system (e.g. crèches). In order to raise attainment and enhance social cohesion, the Ministry of Education introduced the éducation précoce in 1998, a non-compulsory preschool year, and established the maisons relais pour enfants (MRE) in 2005, a flexible and integrative form of extra-familial childcare for children. Luxembourgish was perceived to be the language of integration and became the lingua franca in all state-funded institutions. Nevertheless, multilingualism was a reality. An ethnographic study in several crèches showed that the multilingual carers and the emergent multilingual children drew on several languages. This tolerance for language diversity gave way to monolingual practices whenever the carers wished to cultivate Luxembourgish. At these moments, they reprimanded children for using their home language (Neumann, 2015; Seele, 2015). A study in the éducation précoce similarly indicated that some practitioners allowed children to use their home languages (MENJE \& INSIDE, 2015)

Language policies in the ECEC sector changed in 2017 and called for multilingual education for children from birth to five in both formal and non-formal education. The aims of the new programmes include the development of openness, 
interest in language learning, confidence in language use, and social competences. The focus on multilingualism is expected to prepare young children to the multilingual education system at primary and secondary school, and develop the social skills needed to participate in a competitive international world (MENJE, 2017a, b).

\section{Methodology}

As part of the larger researcher project 'Developing multilingual pedagogies in Early Childhood' (MuLiPEC), the present study investigates as its main research question the influence of the professional development course on attitudes and language learning activities. The sub-questions read as follows:

1. How and to what extent did the PD influence the practitioners' attitudes towards multilingualism, Luxembourgish and home languages?

2. How and to what extent did the PD influence the activities implemented to develop Luxembourgish and the children's home languages?

We hypothesized that the professional development course will positively influence the practitioners' attitudes towards multilingualism, in general, and towards the development of Luxembourgish and home languages, in particular (Datler et al., 2013; Kratzmann et al., 2017; Sachse et al., 2016).

\subsection{The Professional Development Course}

The research team offered two fifteen-hour professional development courses on the development of multilingual education. Forty-six teachers and carers attended the courses, held between May and July and September and November 2016. We developed a model of PD that was collaborative and performance-based, encouraged reflection (Egert, 2015; Egert at al. 2018; Gaikhorst et al., 2017) and was grounded in effective early years practice (De Houwer, 2009; Hindman \& Wasik, 2008; List, 2010). Based on claims of practitioners' poor competences (DJI, 2011; Thoma \& Tracy, 2012) and the inconsistency between their beliefs and practices (Kratzmann et al., 2013; MENJE \& INSIDE, 2015; Viernickel et al., 2013), the course focused on attitudes and the development of knowledge and skills within an enquiry-based framework (Egert 2015; Trodd \& Dickerson, 2018). The first three sessions examined changes in the perspectives of bilingualism (García \& Li Wei, 2014), learning theories, ways of valuing home languages, language-modelling and interaction-supporting strategies, and methods of developing Luxembourgish, French and German (the language the children become literate in Year 1). For instance, the practitioners learned about various ways of telling stories and of working with rhymes before they tried out specific strategies and activities. They were asked to video-record the activities and bring the videos to the sessions. We then analysed the video-recorded activities with the aim of training the practitioners in noticing specific language-supportive strategies (Star \& Strickland, 2008).

\subsection{Sample}

The 46 practitioners, who had enrolled themselves on the course through a ministerial website or an email to the university, were asked to complete a questionnaire prior and after the course. The final sample consisted of the 44 professionals who completed both. Of these, 20 worked in crèches or maisons relais. The remaining 24 worked in an éducation précoce or a preschool. While preschool teachers work alone in a class, a teacher and a carer co-teach in the éducation précoce. This explains the higher number of carers compared to the teachers enrolled. All participants were multilingual although their language background and daily practices differed. The native-speaking Luxembourgers had learned languages sequentially mainly at school and used predominantly Luxembourgish at home. Other participants grew up bilingually and raised their own children bilingually. All communicated in both the official languages of the country and others in their institution. Twenty-eight participants had groups with up to seven different home languages. Table 1 provides an overview of the background of the practitioners.

Table 1. Participants' background

\begin{tabular}{|c|c|c|c|c|c|}
\hline Participants & Age & Qualification & Workplace & Work Location & $\begin{array}{l}\text { Number of languages } \\
\text { in the group }\end{array}$ \\
\hline Total $=44$ & $\begin{array}{l}\text { Less than 30: } \\
\mathrm{N}=10 \\
30-39: \mathrm{N}=20 \\
\text { More than 39: } \\
\mathrm{N}=24\end{array}$ & $\begin{array}{l}\text { Carers: } \mathrm{N}=24 \\
\text { Teachers: } \mathrm{N}=14 \\
\text { Other qualification: } \\
\mathrm{N}=6\end{array}$ & $\begin{array}{l}\text { Preschool: } \mathrm{N}= \\
15 \\
\text { Précoce: } \mathrm{N}=10 \\
\text { Crèche: } \mathrm{N}=13 \\
\text { Maison relais: } \mathrm{N} \\
=6\end{array}$ & $\begin{array}{l}\text { Luxembourg } \\
\text { City: } 15 \\
\text { South: } 13 \\
\text { East: } 5 \\
\text { West: } 6 \\
\text { North: } 5\end{array}$ & $\begin{array}{l}2-5: N=16 \\
6-10: N=24 \\
\text { More than } 10: N=4\end{array}$ \\
\hline
\end{tabular}

\subsection{Methods}

We used both quantitative and qualitative methods. First, we asked all participants to complete a questionnaire prior to and after the PD. This questionnaire had been developed by Kirsch and Seele (MENJE) and drew on the content and specific items of the questionnaires used by Datler et al. (2013), MENJE and INSIDE (2015), Reich (2008) and Kratzmann et al. $(2013$, 2017). It was piloted and reviewed with the help of Curdt-Christiansen, Kratzmann, Lengyel and Panagiotopoulou, 
experts whose work has been mentioned in this article. The final questionnaire comprised four sections of which we explore sections 2 and 3 in the present article:

1. biographical details (e.g. age range, qualification, nationality, languages spoken at home, perceived competence in several languages) and professional details (e.g. length of experience, number of languages in the group, location of the institution)

2. 51 items on a five-point-Likert-scale and open questions on the following topics: language learning and multilingualism in general, attitudes towards the use of Luxembourgish and home languages, attitudes towards the development of Luxembourgish and home languages, and the promotion of home languages. Some examples of items are shown in the section 5.2

3. items on a four-point-Likert-scale and open questions about the type and the frequency of activities used to develop Luxembourgish, French, and home language using books, songs, rhymes

4. questions on partnership with parents, documentation of language learning and professional development courses.

Second, we carried out four interviews with two teachers and four carers selected on the basis of their qualification, the type of institution, and its location: the two teachers, Ms Vivian (pseudonym) and Ms Carla, were employed in a preschool and in an éducation précoce respectively. Ms Jane worked in a précoce, Ms Sandy in a crèche, and Mr Ted and $\mathrm{Mr}$ Chris in a maison relais. The audio-recorded interviews lasted between 30 and 55 minutes and were carried out two months after the PD. The questions addressed attitudes towards multilingualism and multilingual education, the type of activities carried out to develop multiple languages and individual learning during the training. In addition, the interviewer (Kirsch) also aimed to develop some understanding underlying attitudes, activities and changes thereof.

\subsection{Data Analysis}

To analyse the data of the questionnaire, we carried out the following statistical analyses. We conducted paired samples $t$-test to see whether there were significant differences in attitudes to multilingualism and practices in general, and Luxembourgish and home languages in particular, before and after the training. Next, we conducted correlational analysis to examine potential links between the attitudes towards multilingualism, Luxembourgish and home languages, and activities. Although the findings are tentative due to the small sample size, the findings can be informative owing to the triangulation of the methods.

To analyse the interviews, we used thematic analysis (Braun \& Clarke, 2006) supported by the software Nvivo and looked for common themes in the transcribed interviews. Based on our literature review, we looked for categories relating to attitudes, beliefs and activities but we also proceeded inductively and developed some categories related to the PD and professional learning. The codes in the category beliefs, for example, related to additive bilingualism, bilingualism as an asset, competence, language separation, and language ideologies. Codes related to knowledge and skills included among others knowledge about language learning and planning skills. Those relating to PD included content (e.g. pedagogical principles, strategies, activities) and methods of learning (e.g. reflection). At the level of professional learning, we coded for improved knowledge and understanding, new perspectives, and changed practices. Next, we compared these findings across participants and triangulated the findings of the interviews and the questionnaire (Flick, 2011).

\section{Findings}

The following two sections present the findings of the questionnaires and the interviews in relation to changes of attitudes and practices.

\subsection{Findings From the Questionnaire}

The results from the questionnaires will be presented with regards to three major topics: the practitioners' attitudes towards, firstly, multilingualism in general, secondly, the development of Luxembourgish, and, thirdly, the importance of promoting children's home languages. These themes will be explained in turn and related each time to the activities that the practitioners carried out to develop languages.

The topic of multilingualism included 5 items presented as statements regarding the meaning of multilingualism (e.g. 'Being multilingual means being able to use multiple languages fluently and accurately'). The second topic focuses on the development of Luxembourgish and comprises, firstly, interest in the exclusive development of Luxembourgish (5 items; e.g. 'I speak exclusively Luxembourgish with the children'), and, secondly, organising activities in Luxembourgish (11 items; e.g. 'Through rhymes, songs, role-plays, the use of puppets'). The third topic, which focuses on home languages, is divided into, firstly, the development of home languages (6 items; e.g. 'The development of the home language is a pre-condition for the acquisition of other languages'), secondly, the promotion of home languages 
(6 items; e.g. 'I show children that their family languages are important and valued'), and, thirdly, the organisation of activities in home languages (10 items; e.g. 'singing songs',' reciting rhymes', 'telling stories'). To explore possible differences between attitudes towards multilingualism in general, and the development of Luxembourgish and the promotion of home languages, in particular, before and after the course, we conducted paired $t$-test (H1). In addition, to explore the links between the practitioners' attitudes towards multilingualism, and the development of Luxembourgish and home languages, we conducted correlational analysis.

5.1.1 Practitioners' Attitudes Towards Multilingualism, Luxembourgish and Home Languages and the Activities Carried out to Develop Languages Before and After the Training

Firstly, the results showed no significant differences between the practitioners' attitudes towards multilingualism before the course, at Time 1, $(M=20.52, S D=2.65)$ and after the course, at Time $2(M=20.43, S D=2.60), t(41)=.22, p=$ 827. Secondly, and by contrast, there were significant differences in the professionals' interest in Luxembourgish before $(M=15.47, S D=3.81)$ and after $(M=13.72, S D=3.45)$ the PD, whereby the interest in Luxembourgish significantly decreased, $t(42)=3.62, p<.001$. Although this interest decreased, we found a significant increase in activities in Luxembourgish before $(M=44.13, S D=5.29)$ and after $(M=46.53, S D=3.55)$ the course, $t(37)=-3.51, p<.001$. The results are, however, mixed; we found significant differences before and after the course with some activities but not all. For example, there was a significant increase in singing songs in Luxembourgish before $(M=4.48, S D=0.85)$ and after $(M=4.66, S D=0.68)$ the course, $t(44)=-2.71, p<.050$, in rhyming before $(M=3.17, S D=1.38)$ and after $(M=3.73$, $S D=1.10)$ the course (however, note the large SDs), $t(41)=-3.69, p<.001$, in using pictures before $(M=4.30, S D=$ $1.02)$ and after $(M=4.66, S D=0.48)$ the course, $t(44)=-2.33, p<.001$. We did not find any significant differences in the daily use of Luxembourgish $(p=.160)$, reading books and storytelling $(p=.812)$, use of games $(p=.078)$, listening to CDs $(p=.267)$, and specific activities to develop Luxembourgish $(p=.834)$. Thirdly, we found a significant increase in the professionals' interest in the children's home languages from $(M=26.30, S D=2.71)$ to $(M=27.77, S D=2.46)$ after the course, $t(42)=-2.88, p<.010$. The same significant increase was noted regarding the practitioners' interest in promoting home languages before $(M=23.91, S D=2.25)$ and after $(M=25.89, S D=2.63)$ the course, $t(43)=-4.52, p$ $<.001$, and their organised activities in home languages before $(M=27.52, S D=6.45)$ and after the course $(M=31.69$, $S D=6.53), t(41)=-5.03, p<.050$. For example, there was a significant increase in singing before $(M=3.16, S D=1.38)$ and after $(M=3.57, S D=1.21)$ the course, $t(44)=-2.66, p<.050$, in rhyming before $(M=3.98, S D=1.11)$ and after $(M=4.50, S D=0.79)$ the course, $t(44)=-2.82, p<.010$, and in storytelling before $(M=2.16, S D=1.22)$ and after $(M$ $=2.70, S D=1.09)$ the course, $t(44)=-3.26, p<.010$. By contrast, there were no significant differences in daily communication $(p=.750)$ and the use of home languages in free play $(p=.486)$ before and after the PD. In sum, the promotion of children's home languages in the professionals' daily practice increased significantly, particularly in planned activities such as singing, rhyming and storytelling. The findings are summarised in Table 2.

Table 2. Results of the paired t-test

\begin{tabular}{l|l|l|l}
\hline & Time 1 (M, SD) & Time 2 (M, SD) & $p$-value \\
\hline Attitudes towards multilingualism & $20.52(2.65)$ & $20.43(2.60)$ & $p=.827$ \\
\hline Developing Luxembourgish & $15.47(3.81)$ & $13.72(3.45)$ & $p<.001$ \\
\hline Activities in Luxembourgish: & $44.13(5.29)$ & $46.53(3.55)$ & $p<.001$ \\
\hline (a) Singing songs & $4.48(0.85)$ & $4.66(0.68)$ & $p<.050$ \\
\hline (b) Rhyming & $3.17(1.38)$ & $3.73(1.10)$ & $p<.001$ \\
\hline (c) Using pictures & $4.30(1.02)$ & $4.66(0.48)$ & $p<.001$ \\
\hline (d) Daily use of Luxembourgish & $4.20(0.70)$ & $4.23(0.61)$ & $p=.812$ \\
\hline (e) Reading books and storytelling & $3.56(1.05)$ & $3.81(0.96)$ & $p=.078$ \\
\hline (f) Use of games & $3.07(1.28)$ & $3.23(1.01)$ & $p=.267$ \\
\hline (g) Specific activities & $3.64(1.24)$ & $3.59(1.17)$ & $p=.834$ \\
\hline Developing home languages & $26.30(2.71)$ & $27.77(2.46)$ & $p<.010$ \\
\hline Promoting home languages & $23.91(2.25)$ & $25.89(2.63)$ & $p<.010$ \\
\hline Activities in home languages: & $27.52(6.45)$ & $31.69(6.53)$ & $p<.050$ \\
\hline (a) Singing & $3.16(1.38)$ & $3.57(1.21)$ & $p<.050$ \\
\hline (b) Rhyming & $3.98(1.11)$ & $4.50(0.79)$ & $p<.010$ \\
\hline (c) Storytelling & $2.16(1.22)$ & $2.70(1.09)$ & $p<.010$ \\
\hline (d) Daily communication & $4.48(1.13)$ & $4.52(1.09)$ & $p=.750$ \\
\hline (e) Free play & $4.82(0.66)$ & $4.77(0.74)$ & $p=.486$ \\
\hline & & & \\
\hline & & & \\
\hline
\end{tabular}


Note: Significant results are in italics.

\subsubsection{Links Between the Practitioners' Attitudes, Interest in Developing Languages and Activities}

To explore the links between the professionals' attitudes towards multilingualism, their interest in developing languages and the implementation of activities, we conducted correlational analysis. Only significant and meaningful correlations will be presented (see Table 3). Firstly, the results show that, at Time 1, the practitioners' attitudes towards multilingualism were significantly positively correlated with their attitudes towards multilingualism at Time $2, r(42)=.43$, $p<01$, their interest in promoting home languages, $r(42)=.36, p<05$, and the ways of promoting home languages, $r(43)$ $=.56, p<001$, at Time 1 . However, their attitudes towards multilingualism were significantly negatively correlated with their interest in Luxembourgish, $r(42)=-.38, p<05$. At Time 2, their attitudes towards multilingualism were significantly positively correlated with the importance attributed to promoting home languages, $r(43)=.41, p<.010$, and with ways of promoting of home languages, $r(43)=.33, p<.050$. However, attitudes towards multilingualism at Time 2 were significantly negatively correlated with the interest in Luxembourgish at both Time $1, r(43)=-.30, p<.050$, and Time 2 , $r(43)=-.40, p<.010$. The professionals seem to perceive the development of Luxembourgish and the promotion of home languages in opposing terms. We found only one positive correlation regarding the development of Luxembourgish and home languages: the implementation of activities in Luxembourgish at Time 2 was correlated positively with the implementation of the activities in home languages at Time 2.

Table 3. Correlations, Means, Standard Deviations, and Reliabilities across Two Measurement Occasions

\begin{tabular}{|c|c|c|c|c|c|c|c|c|c|c|c|c|c|c|c|c|c|}
\hline Measures & Age & LAN & QLF & EXP & WLO & MT1 & MT2 & LDT1 & LDT2 & LAT1 & LAT2 & HLDT & $1 \mathrm{HLDT}$ & $2 \mathrm{HLPT}$ & $1 \mathrm{HLPT}$ & $1 \mathrm{HLAT}$ & 1 HLAT2 \\
\hline \multicolumn{18}{|l|}{ Teachers background } \\
\hline \multicolumn{18}{|l|}{ Age } \\
\hline Language & -.43 & & & & & & & & & & & & & & & & \\
\hline Qualification & .08 & -.06 & & & & & & & & & & & & & & & \\
\hline Experience & .67 & -.38 & .01 & & & & & & & & & & & & & & \\
\hline Work location & .20 & -.41 & -.27 & .06 & & & & & & & & & & & & & \\
\hline \multicolumn{18}{|l|}{ Multilingualism } \\
\hline Multilingualism T1 & -.15 & .10 & -.13 & -.04 & .06 & & & & & & & & & & & & \\
\hline Multilingualism T2 & -.23 & .19 & -.16 & -.02 & .12 & .43 & & & & & & & & & & & \\
\hline \multicolumn{18}{|l|}{ Luxembourgish } \\
\hline Development T1 & .22 & -.30 & -.16 & .11 & .13 & -.38 & -.30 & & & & & & & & & & \\
\hline Development T2 & .20 & -.36 & -.15 & .16 & .08 & -.15 & -.40 & .62 & & & & & & & & & \\
\hline Activities T1 & -.19 & .07 & -.49 & -.05 & .23 & .20 & .02 & -.01 & .03 & & & & & & & & \\
\hline Activities T2 & -.32 & .02 & -.35 & -.09 & .24 & -.06 & .09 & .13 & -.08 & -.61 & & & & & & & \\
\hline \multicolumn{18}{|l|}{ Home languages } \\
\hline Development T1 & -.34 & .25 & .12 & -.28 & .04 & .36 & .17 & -.61 & -.29 & -.01 & -.01 & & & & & & \\
\hline Development T2 & -.38 & .24 & -.07 & -.23 & .09 & -.07 & .41 & -.14 & -.39 & -.14 & .03 & .17 & & & & & \\
\hline Promotion T1 & -.24 & .23 & .05 & r.25 & -.09 & .56 & .11 & -.39 & -.38 & .16 & -.05 & .47 & .13 & & & & \\
\hline Promotion T2 & -.31 & .24 & -.20 & -.15 & -.12 & .01 & .33 & -.07 & -.35 & -.24 & -.09 & .06 & .60 & .30 & & & \\
\hline Activities T1 & -.41 & .59 & -.12 & -.29 & -.23 & .19 & -.02 & -.42 & -.39 & .27 & .21 & .35 & .02 & .44 & .09 & & \\
\hline Activities T2 & -.46 & .37 & -.32 & -.39 & -.05 & .12 & .13 & -.23 & -.43 & .36 & .52 & .03 & .25 & .25 & .26 & .66 & \\
\hline \multicolumn{18}{|l|}{ Descriptives } \\
\hline Mean & 2.07 & 1.45 & 1.70 & 2.44 & 2.30 & 20.51 & 20.30 & 15.47 & 13.59 & 43.78 & 46.65 & 26.30 & 27.73 & 23.91 & 25.89 & 27.66 & 31.69 \\
\hline Standard deviation & .74 & .63 & .70 & .73 & 1.25 & 2.62 & 2.70 & 3.81 & 3.52 & 5.57 & 3.51 & 2.71 & 2.44 & 2.25 & 2.62 & 6.33 & 6.52 \\
\hline Reliability & -- & -- & -- & -- & -- & .49 & .48 & .63 & .64 & .68 & .49 & .53 & .66 & .01 & .44 & .69 & .73 \\
\hline
\end{tabular}

Note. Correlations reaching significance at .05 are indicated in italics. Correlations reaching significance at .01 are indicated in bold. LAN = Language, $\mathrm{QLF}=$ Qualification, $\mathrm{WLO}=$ Work location, MT1 $=$ Multilingualism T1, MT2 = Multilingualism T2; LDT1 = Luxembourgish development T1; LDT2 = Luxembourgish development T2, LAT1 = Luxembourgish activities T2; HLDT1 = Home language development T1; HLDT2 = Home language development T2; HLPT1 = Home language promotion T1; HLPT2 = Home language promotion T2; HLAT1 = Home language activities T1; HLAT2 $=$ Home language activities T2; T1 $=$ Time $1, \mathrm{~T} 2=$ Time

\subsection{Findings From the Interviews}

The six participants interviewed valued the input on multilingualism, learning theories and language activities, as well as the opportunity to relate theory and practice. They all concluded that the PD had been transformative in that they changed 
some attitudes, developed some knowledge and skills, and begun to introduce some activities. These aspects will be explained in turn.

Regarding attitudes, we found that all interviewees perceived multilingualism as an asset. However, most were initially skeptical about multilingual education. They argued for a focus on Luxembourgish and mentioned several reasons. Some representative quotes follow.

So far, we have always focussed on Luxembourgish. We think that the children need to master Luxembourgish when they enroll in preschool. But this course was an eye-opener and we became aware that there is something else than Luxembourgish. (Interview with Ms Carla)

The parents have always this panic that the kids should learn Luxembourgish. They have these expectations, also of me. (Interview with Ms Vivian)

Both teachers and several carers explained that they needed to follow the national curriculum and prepare children for primary school. Additionally, parents intentionally enrolled their child in their institution to learn Luxembourgish. The existing national language policy called for Luxembourgish. Furthermore, several practitioners believed that they should devote all their time to Luxembourgish because many young children had little knowledge of Luxembourgish. As seen in the quote below, Ms Carla and Ms Jane felt that their three-year olds made little progress and, as a result, they felt even more under pressure to develop competence in this language. Furthermore, like other interviewees, they feared that input in the home languages would impede progress in Luxembourgish.

We had a negative picture of our children for a long time. They made only little and very slow process. We asked ourselves a lot of questions. But the other people gave us a lot of positive feedback and we understood that we had achieved a lot. (Interview with Ms Carla)

The beliefs concerning the need to focus on Luxembourgish have to be seen in relation to the practitioners' knowledge. Through the input in the PD, the interviewees had deepened their understanding of language learning. For instance, Ms Carla and Ms Jane, who had assessed the pupils' language skills as low, realised that young emergent bilinguals need more time to develop language skills than they had imagined. They also understood that the children's receptive skills were far more developed than their productive skills. On a different note, they witnessed that the other participants, who had analysed their home-made videos, evaluated the competences of these three-year olds in a more positive light. As a result, they began to change their negative perceptions of the children's competences. Furthermore, the interviews showed that the practitioners came to understand that languages are learned in a dynamic way and that the use of home languages does not impede the learning of Luxembourgish. The following quotes of Ms Vivian and Mr Chris indicate how the practitioners' own and the children's experiences of using languages flexibly, affected their attitudes.

I became aware that the children did not learn less Luxembourgish when I told them from time to time stories in German or French. (Interview with Ms Vivian)

I have to say that I felt, well, it was almost a relief. I accepted that the children used their home language and I did not have to think, do I have to step in or do I insist that they speak Luxembourgish. This was not a question anymore. I knew that I took account of the children's language needs. (Interview with Mr Chris)

Additionally, all practitioners developed some understanding of language-supporting strategies and learned to pay more attention to the children's linguistic needs. The request to video-record activities pushed them to pay attention to their own language use and the ways in which they encouraged child talk. While all carers maintained that they worked in a child-centred way based on the children's needs, they noticed through the videos that they often offered 'pre-structured input' (Ms Sandy) and worked at the word level although many children were able to construct sentences ( $\mathrm{Mr} \mathrm{Ted}$ and $\mathrm{Mr}$ Chris).

Finally, the PD made the practitioners reflect on their own and the children's language use. As seen before, the interviewees initially expressed negative views on multilingual education. While watching their own videos and discussing their practices, they noticed that home languages were very much alive in their institution. For instance, they all let the children communicate in their home language, for example during free play, and some used home languages to calm children down. Ms Clara and Ms Jane reported that they spontaneously spoke French, German or Portuguese to children when necessary. Ms Sandy translanguaged frequently. Like Mr Ted and Mr Chris, she realised that the use of home languages contributed to the children's well-being and confidence. In addition, she felt 'free' because she did not have to forbid the use of Luxembourgish and could use several languages herself. The input during the PD and the reflections helped the professionals understand that they needed to use languages consciously and strategically and plan activities where all, not only some children could use their home languages. Most participants began to open up to multilingual education when they realised the success of the activities carried out in languages other than Luxembourgish. They experienced that the children were motivated and participated well in these activities and continued to develop skills 
in Luxembourgish albeit using other languages as well. Ms Clara reported that she reconsidered her position on multilingual education when she saw how the children took to a French song they had sung only twice. The children sang it spontaneously, effortlessly and with enjoyment, which contrasted with 'the hard work of learning Luxembourgish'. The preschool teacher similarly witnessed the success of the activities in languages other than Luxembourgish.

I did not have a multilingual practice until I began this course. I became aware how focussed I was on Luxembourgish. Without this professional development, I would never have taught rhymes in German and French. I would probably not have told them stories in a language other than Luxembourgish. I would not have changed my perspective. (Interview with Ms Vivian)

In sum, the PD had a positive influence on the professionals' knowledge, skills and attitudes. The practitioners also realised that there was no conflict between the development of Luxembourgish and home languages and began to introduce more activities in languages other than Luxembourgish. However, it remains to be seen whether this effect will be sustained. Ms Vivian mentioned that she had not had time to consolidate her practice as the course had come late in the academic year. Others stated they would continue to use the children's home languages to ensure their well-being. Sustainability is related to the potential transfer of the practitioners' learning and their agency within the institution. In that respect, the findings showed that all interviewees entered in dialogue with their colleagues. Ms Jane and Ms Sandy convinced colleagues to carry out some activities in languages other than Luxembourgish and $\mathrm{Mr}$ Ted and Mr Chris presented the main concepts of the PD course in a team meeting to reassure their colleagues who felt unsecure and voiced negative attitudes towards multilingual education.

\section{Discussion}

Our findings show that the PD had some positive effect on the teachers' and carers' attitudes, knowledge, and learning activities, in line with the findings of other scholars (Egert et al., 2018; Hamre et al., 2012; Ottley et al., 2015; Sachse et al., 2016).

The questionnaire indicated that the practitioners hold positive attitudes towards multilingualism before the course. Other European studies (Fried et al., 2013; Kratzmann et al., 2013, 2017; Viernickel et al., 2013) and an earlier study in the éducation précoce in Luxembourg (MENJE \& INSIDE, 2015) similarly demonstrated that professionals viewed multilingualism positively. These general attitudes towards multilingualism remained positive throughout the course, thus, the PD did not change these. However, it had an effect on the attitudes towards the development of Luxembourgish and the interest in home languages. The correlations and the interviews indicated that the professionals appeared to believe that promoting Luxembourgish as well as home languages were conflicting aims. This finding is reminiscent of Khan-Svik's (2002) study in Austria. She found that the desire to develop competency in German was negatively correlated with positive attitudes towards multilingualism. Supporting both multilingualism and German was perceived to be incompatible. Given that Luxembourg is a multilingual country with three official languages including Luxembourgish and French, this tension between multilingualism and Luxembourgish may seem unexpected. However, it reflects the complex relationship between Luxembourgish and multilingualism that Luxembourgers hold in society at large (Horner $\&$ Weber, 2008). The Luxembourgish language is a national symbol but multilingualism is necessary for survival.

The interviews of the participants in Luxembourg also indicated that the practitioners reconsidered their views through the PD. They came to understand the reasons underpinning their focus on Luxembourgish, referring among others to national and local policies, pressure from other teachers and parents, and erroneous conceptions about language learning. In addition, their reflections on their own and the children's language use made them realise that they used languages in a more dynamic way than they had imagined. Their everyday practice was multilingual. Earlier ethnographic studies by Neumann (2015) and Seele (2015) in non-formal educational institutions in Luxembourg confirmed this flexible bilingualism (Blackledge \& Creese, 2010). The practitioners' reflections may help explain their change of attitudes after the PD: their interest in in using Luxembourgish to the exclusion of other languages decreased and their interest in home languages and the promotion thereof increased.

Furthermore, the training positively influenced knowledge of multilingualism and language learning. The questionnaire and the interviews indicated that some practitioners believed that the use of home languages impedes the learning of Luxembourgish. Their understanding of the acquisition of multiple languages may have been influenced by the idea that languages are separated in the brain and, therefore, that adults needed to separate languages to help children acquire them effectively. The PD successfully dispelled this belief by familiarising the professionals with dynamic theories of bilingualism. This new understanding of multilingualism and language learning enabled the professionals to understand that translanguaging was a normal and legitimate practice which did not hinder language learning (García \& Seltzer, 2016). This helps explain why some practitioners felt relieved that they could use home languages.

In addition, the training reinforced the practitioners' understanding of the importance of interactions and language-supporting strategies (Buschmann and Sachse, 2018). The questionnaire and the interviews revealed that the 
practitioners associated the use of home languages with the children's well-being and understood the relevance of talking to children both in Luxembourgish and in their home languages. Because the children could communicate in their home languages during free-play before the course, it is understandable that we did not find an increase in their use of home languages during free-play after the course. While it is encouraging that children and adults used home languages, these results shed no light on the quality of the interactions or the number of languages used. Thus, it may be the case that French or Portuguese were used frequently while other languages such as Arabic were rarely or never used. One can hypothesise that the children in these settings were likely to experience all or most languages as legitimate while accepting that Luxembourgish carries most weight. Their sense of multilingual identity may also be enhanced (Cummins, 1996).

A further positive effect of the course was the implementation of activities both in Luxembourgish and home languages. The increase in activities in Luxembourgish testifies to the professionals' understanding of the necessity to provide children with varied and frequent input to assist their language development. As for the rise in language activities in home languages, this was expected given that the practitioners were required to carry out at least two activities in French or the children's home languages during the PD, and that they had done at best few or, perhaps, no such activities before the course. Few had developed a practice of systematically promoting home languages, for example through using books or songs. In this sense, the professionals in Luxembourg resembled those in Germany (Kratzmann et al., 2013, 2017; Viernickel et al., 2013). Our request to implement activities in languages other than Luxembourgish led the practitioners to plan language activities more systematically. The perceived success of activities promoting either Luxembourgish or other languages and the children's motivation to engage in such activities help explain the positive correlation between activities in Luxembourgish and home languages at Time 2. The practitioners were more focussed on languages and began to carry out more activities independently of the language.

The activities in activities other than Luxembourgish consisted of telling stories, doing finger or table rhymes, and singing songs. These language activities are typical in ECEC (Hindman \& Wasik, 2008; List, 2010; MENJE \& INSIDE, 2015; Viernickel et al., 2013). The interviews show that the experience of carrying out activities and the success of these encouraged practitioners to adopt a more child-centred approach and rethink their ambiguous or negative perspective of multilingual education.

The main limitation of the present study is the small sample size necessary for more robust quantitative analyses that would explore the effects of the professional development. However, within our project, we only had the resources to run two training courses. Motivated practitioners decided to attended the training. This is a sign of their interest and may bias the outcomes. Change, however, always begins with motivated professionals. In a future study, we would involve more practitioners (Prenger et al., 2017) and examine the relationship between their background variables (e.g. age, language use) and their attitudes and practices.

\section{Conclusion}

This professional development course had some positive effect on the practitioners, for instance on their knowledge of language learning, their openness towards multilingual education, and their implementation of language activities. While we did not investigate professional learning as such, it became clear that the combination of instruction, the implementation of specific activities by the practitioners, the documentation and analysis of their practice, and the feedback offered productive learning opportunities (Gaikhorst et al., 2017; Prenger et al., 2017). The performance-based assignments and the documentation led the practitioners to reflect on language policies, beliefs and practices, construct new knowledge, and implement some change. In this sense, this study contributes to research into the effectiveness of transformative models of PD (Gogolin et al., 2010). In addition, it is so far one of few studies in Europe that is based in the ECEC sector and focusses on multilingual education (Buschmann \& Sachse, 2018).

One criterion for the effectiveness of professional training may be the sustainability of positive influences. Waters and Payler (2015), for instance, argue that PD should enable practitioners to undergo 'systematic, sustainable and transformative change' (p. 163). The competence to critically reflect, consider other perspectives and rethink one's own can be the starting point both for transformation and the sustainability of change (McLeod, 2015; Trodd \& Dickerson, 2018). We are unable to comment on sustained practices but we agree that short-term enquiry-based programmes like ours need to be followed up, ideally with professional learning in learning communities, individual coaching, and the involvement of management (Buschmann \& Sachse, 2018; Gaikhorst et al., 2017; Markussen-Brown et al., 2017; Werner et al., 2016). Coaching provides trainers with opportunities to observe daily practice and give productive feedback. Involving the management team guarantees that the latter support and know how to support staff. In our project 'MuliPEC' we continued to work with seven practitioners over the academic year 2016/17. We observed their practices, coached them, and invited them to six meetings to analyse the video-recordings of their practices with us. Our preliminary findings show that this additional training contributed to further positively influence the professionals' attitudes towards 
multilingual education and practices. Videos of their practices are displayed on the project's website (https://mulipec.uni.lu). We hope that they come useful in other PD trainings.

\section{Acknowledgement}

"This research project is supported by the Fonds National de la Recherche (FNR) [grant number FNR9989225] and the Ministry of National Education, Childhood and Youth [MuLiPEC]."

\section{References}

Abreu, L. (2015). Changes in beliefs about language learning and teaching by foreign language teachers in an applied linguistics course. Dimension, 136-163.

Bandura, A. (1986). Social foundations of thought and action: A social cognitive theory. Englewood Cliffs, NJ: Prentice Hall.

Başöz, T., \& Çubukçu, F. (2014). Pre-service EFL teachers' attitudes towards Computer Assisted Language Learning (CALL). Procedia - Social and Behavioral Sciences, 116, 531-535. https://doi.org/10.1016/j.sbspro.2014.01.253

Bernat, E., \& Gvozdenko, I. (2005). Beliefs about language learning: Current knowledge, pedagogical implications, and new research directions. TESL-EJ, 9(1), 1-21.

Blackledge, A., \& Creese, A. (2010). Multilingualism: A critical perspective. London, England: Continuum International.

Braun, V., \& Clarke, V. (2006). Using thematic analysis in psychology. Qualitative Research in Psychology, 3, 77-101. https://doi.org/10.1191/1478088706qp063oa

Burgess, A. K., Lundgren, K. A., Lloyd, J. W., \& Pianta, R. C. (2001). Preschool teachers' self-reported beliefs and practices about literacy instruction. Ann Arbor, MI: Center for the Improvement of Early Reading Achievement.

Buschmann, A., \& Sachse, S. (2018). Heidelberg interaction training for language promotion in early childhood settings (HIT). European Journal of Education, 53(1), 66-78. https:// doi.org/10.1111/ejed.12263

Cummins, J. (1996). Negotiating identities: Education for empowerment in a diverse society. Los Angeles, CA: California Association for Bilingual Education.

Datler, W., de Cillia, R., Garnitschnig, I., Sobzak, E., \& Zell, K. (2013). Forschungsprojekt: Spracherwerb und lebensweltliche Mehrsprachigkeit im Kindergarten [Research project: Language acquisition and lifelong multilingualism in preschool]. Perspektiven, 1, 12-16.

De Houwer, A. (2009). Bilingual first language acquisition. Bristol, England: Multilingual Matters.

Desimone, L. M., Smith, T., \& Philips, K. (2013). Linking student achievement growth to professional development participation and changes in instruction: A longitudinal study of elementary students and teachers in title I schools. Teachers College Record, 115(5), 1-46.

Deutsches Jugendinstitut [DJI]. (2011). Sprachliche Bildung. Grundlagen für die kompetenzorientierte Weiterbildung [Language education. Foundations for competence-oriented professional development]. München, Germany: Deutsches Jugendinstitut.

Egert, F. (2015). Meta-analysis on the impact of in-service professional development programs for preschool teachers on quality ratings and child outcomes [Doctoral dissertation, Otto-Friedrich-University, Bamberg, Germany]. Retrieved from https://opus4.kobv.de/opus4-bamberg/files/45682/EGERTFranziskaDisssekA3a.pdf

Egert, F., Fukking, R. G., \& Eckhardt, A. G. (2018). Impact of In-Service Professional Development Programs for Early Childhood Teachers on Quality Ratings and Child Outcomes: A Meta-Analysis. Review of Educational Research June, 88(3), 401-433. https://doi.org/10.3102/0034654317751918

Flick, U. (2011). Triangulation. Eine Einführung. [Triangulation. An introduction.] Wiesbaden: VS Verlag.

Fried, L., Briedigkeit, E., Eden, L., Faeseke, J., Graffunder, A., KleineBrockhoff, A., \& Lehmann, L. (2013). Sprachförderpraxis in der Wirtschaftsmetropole Ruhr aus der Perspektive pädagogischer Fachkräfte [Language promotion practice in the economic metropolis Ruhr from the perspective of educational specialists]. Dortmund, Germany: Technical University of Dortmund.

Gaikhorst, L., Beishuizen, J. J. J., Zijlstra, B. J. H., \& Volman, M. L. L. (2017). The sustainability of a teacher professional development programme for beginning urban teachers. Cambridge Journal of Education, 47(1), 135-154. https:// doi.org/ 10.1080/0305764X.2015.1125449

García, O., \& Seltzer, K. (2016). The Translanguaging current in language education. In B. Kindenberg (Eds.) Flerspråkighet som resurs [Multilingualism as a resource] (pp. 19-30). Stockholm, Sweden: Liber. 
García, O., \& Li, W. (2014). Translanguaging: language, bilingualism and education. New York, NY: Palgrave Macmillan.

Girolametto, L., Weitzman, E., \& Greenberg, J. (2012). Facilitating emergent literacy: Efficacy of a model hat partners speech-language pathologists and educators. American Journal of Speech-Language Pathology, 21(1), 47-63. https://doi.org/10.1044/1058-0360(2011/11-0002)

Gogolin, I. (1994). Der monolinguale Habitus der multilingualen Schule [The monolingual habitus of the multilingual school]. Münster, NY: Waxmann.

Gogolin, I., Dirim, I., Klinger, T., Lange, I., Lengyel, D., Michel, U., ... Schwippert, K. (2011). Förderung von Kindern und Jugendlichen mit Migrationshintergrund. FörMig. Bilanz und Perspektiven eines Modellprogramms [Supporting children and adolescents with migration background. FörMig. Conclusion and perspectives of a model programme.] (Vol. 7). Münster, NY: Waxmann.

Grin, F. (2003). Language planning and economics. Current Issues in Language Planning, 4(1), 1-66. https://doi.org/10.1080/14664200308668048

Hamre, B. K., Pianta, R. C., Burchinal, M., Field, S., Locasale-Crouch, J., Downer, J. T., Howes, C., LaParo, K., \& Scott-Little, C. (2012). Supporting effective teacher-child interactions through coursework: Effects on teacher beliefs, knowledge, and observed practice. American Educational Research Journal, 49(1), 88-123. https://doi.org/10.3102/0002831211434596

Heller, M. (2006). Linguistic minorities and modernity: A sociolinguistic ethnography. London, England: Continuum.

Hindman, A. H., \& Wasik, B. A. (2008). Head Start teachers' beliefs about language and literacy instruction. Early Childhood Research Quarterly, 23(4), 479-492. https://doi.org/10.1016/j.ecresq.2008.06.002

Horner, K., \& Weber, J-J. (2008). The language situation in Luxembourg. Current Issues in Language Planning, 9(1), 69-128. https://doi.org/10.2167/cilp130.0

Khan-Svik, G. (2002). Fragebogenerhebung zur Einstellung von Beschäftigten im Kindergarten zu Einsprachigkeit und Mehrsprachigkeit [Survey about the beliefs on monolingualism and multilingualism of practitioners in preschools]. In S. Buttaroni (Ed.), Vorschulische Intergration durch Sprach(en)Wissen [Intergation into preschool owing to (language) knowledge] (pp. 42-61). Wien, Austria: Bundesministerium für Bildung, Wissenschaft und Kultur.

King, F. (2014). Evaluating the impact of teacher professional development: an evidence-based framework. Professional Development in Education. 40(1), 89-111. https://doi.org/10.1080/19415257.2013.823099

Kirsch, C. (2015). Multilingual Oracies: Ein Bericht einer Weiterbildung zur Förderung der Mündlichkeit anhand von Versen und Bilderbüchern. [Multilingual oracies: A report about a professional development promoting orals skills with rhymes and books.] In MENJE, eds, Beiträge zur Plurilingualen Bildung: Non-formale Bildung und Betreuung in früher Kindheit und im Schulalter. Band 3. Luxembourg: Ministère de l'Éducation nationale, de l'Enfance et de la Jeunesse, 73-100.

Kirsch, C. (2017). Young children capitalising on their entire language repertoire for Language Learning at School. Language, Culture and Curriculum, 31(1), 39-55. https://doi.org/10.1080/07908318.2017.1304954

Kratzmann, J., Jahreiß, S., Frank, M., Ertanir, B., \& Sachse, S. (2017). Einstellungen pädagogischer Fachkräfte in Kindertageseinrichtungen zur Mehrsprachigkeit [Beliefs on multilingualism of practitioners in early years institutions]. Zeitschrift für Erziehungswissenschaft, 20(2), 237-258. https://doi.org/10.1007/s11618-017-0741-7

Kratzmann, J., Lehrl, S., \& Ebert, S. (2013). Einstellungen zum Einbezug der Erstsprache im Kindergarten und deren Bedeutung für die Wortschatzentwicklung im Deutschen bei Kindern mit Migrationshintergrund [Beliefs on the use of the first language in preschool and their effect on the development of German vocabulary of children with migration background]. Frühe Bildung, 2(3), 133-143. https://doi.org/10.1026/2191-9186/a000100

Lengyel, D. (2012). Early childhood education in multilingual settings. In Z. Bekerman Z and T. Geisen (Eds.), International handbook on migration, minorities, and education - Understanding cultural and social differences in processes of learning (pp. 169-187). New York, NY: Springer.

Levin, T., \& Wadmany, R. (2006). Teachers' beliefs and practices in technology-based classrooms: A developmental view. Journal of Research on Technology in Education, 39(2), 157-181. https://doi.org/10.1080/15391523.2006.10782478

Li, L., \& Walsh, S. (2011). Seeing is believing: looking at EFL teachers' beliefs through classroom interaction. Classroom Discourse, 2(1), 39-57. https:// doi.org/ 10.1080/ 19463014.2011.562657 
List, G. (2010). Frühpädagogik als Sprachförderung. Qualifikationsanforderungen für die Aus- und Weiterbildung der Fachkräfte [Early childhood and language development. Qualifications of practitioners for initial training and further development]. München, Germany: Deutsches Jugendinstitut.

Markussen-Brown, J., Juhl, C. B., Piasta, S. B., Bleses, D., Højen, A., \& Justice, L. M. (2017). The effects of languageand literacy-focused professional development on early educators and children: A best-evidence meta-analysis. Early Childhood Research Quarterly, 38, 97-115. https://dx.doi.org/10.1016/j.ecresq.2016.07.002

McLeod, N. (2015). Reflecting on reflection: improving teachers' readiness to facilitate participatory learning with young children. Professional Development in Education, 41(2), $254-272$. https://doi.org/10.1080/19415257.2013.805306

Ministry of National Education, Childhood and Youth [MENJE] and Integrative Research Unit on Social and Individual Development [INSIDE]. (2015). D'Éducation précoce: Mat de Kanner, fir d'Kanner! Evaluationsstudie: Die Éducation précoce als Raum für Bildungs- und Lernprozesse dreijähriger Kinder. Öffentlicher Bericht [The éducation précoce: with children, for children. Evaluation: The éducation précoce as an edcational and learning space fo three-year-olds. Report]. Luxembourg, Luxembourg: Ministry of National Education, Childhood and Youth and the University of Luxembourg.

Ministry of National Education, Childhood and Youth [MENJE]. (2018). Les chiffres clés de l'Éducation nationale: statistiques et indicateurs - Année scolaire 2016-2017 [Key numbers of the national education: statistics and $\begin{array}{llllll}\text { indicators } & - & \text { School } & \text { year } & \text { 2016-20167]. } & \text { Retrieved }\end{array}$ http://www.men.public.lu/fr/actualites/publications/themes-transversaux/statistiques-analyses/chiffres-cles/index.ht $\mathrm{ml}$

Ministry of National Education, Childhood and Youth [MENJE]. (2017a). Une nouvelle approche pour l'apprentissage du français [A new approach to learning French]. Retrieved from http://www.men.public.lu/catalogue-publications/enfance-jeunesse/infos-generales-offre/170926-brochure-info-z/i nfo.pdf

Ministry of National Education, Childhood and Youth [MENJE]. (2017b). D'Zukunft fänkt éischter un [The future begins earlier]. Retrieved

from http://www.men.public.lu/catalogue-publications/enfance-jeunesse/infos-generales-offre/170926-brochure-info-z/i nfo.pdf

National Institute of Statistics and Economic Studies of the Grand Duchy of Luxembourg [STATEC]. (2018). Evolution of total, Luxembourgish and foreign population 1961-2018. Retrieved from: http:// www.statistiques.public.lu / stat /TableViewer /tableView.aspx ?ReportId=12853\&IFLanguage=fra \&MainTheme=2\&FldrName=1

Neumann, S. (2015). Lost in translanguaging? Practices of language promotion in Luxembourgish early childhood education. Global Education Review, 2(1), 23-39.

Neumann, S., Kuhn, M., Tinguely, L., \& Brandenberg, K. (2017). „Weißt Du auch, wie das auf Deutsch heißt?“ Zum frühpädagogischen Umgang mit sprachlicher Diversität in bilingualen Regionen der Schweiz [,,Do you know what this is called in German?" Dealing with language diversity in early childhood in bilingual regions in Switzerland]. In U. Stenger, D. Edelmann, D. Nolte, \& M. Schulz (Eds.), Im Spannungsfeld zwischen Konstruktion und Normativität: Diversität in der Pädagogik der frühen Kindheit [In the tension between construction and normativity: diversity in pedagogy in early childhood] (pp. 253-270). Weinheim, Germany: Beltz Juventa.

Ottley, J. R., Piasta, S. B., Mauck, S. A., O’Connell, A., Weber-Mayrer, M., \& Justice, L. M. (2015). The nature and extent of change in early childhood educators' language and literacy knowledge and beliefs. Teaching and Teacher Education, 52, 47-55. https://doi.org/10.1016/j.tate.2015.08.005

Pajares, F. (1992). Teachers' beliefs and educational research: cleaning up a messy construct. Review of Educational Research, 62(3), 307-332. https:// doi.org/ 10.3102\%2F00346543062003307

Panagiotopoulou, A. (2016). Mehrsprachigkeit in der Kindheit. Perspektiven für die frühpädagogische Praxis [Childhood multilingualism. Perspectives for early childhood] Expertise für das Projekt Weiterbildungsinitiative Frühpädagogische Fachkräfte (WiFF), [Expertise for the project professional development initiative of early years practitioners] (Vol. 46). München, Germany: Deutsches Jugendinstitut.

Pianta, R., Howes, C., Burchinal, M., Bryant D., Clifford R., Early, C., Oscar, B. (2005). Features of pre-kindergarten programs, classrooms, and teachers: Do they predict observed classroom quality and child-teacher interactions? Applied Developmental Science 9(3), 144-159.

Piasta, S. B., Justice, L. M., Cabel, S. Q., Wiggings, A. K., Turnbull, K. P., \& Curenton, S. M. (2012). Impact of 
professional development on preschool teachers' conversational responsivity and children's linguistic productivity and complexity. Early Childhood Research Quarterly, 27(3), 387-400. https://doi.org/10.1016/j.ecresq.2012.01.001

Portolés, L., \& Martí, O. (2018). Teachers' beliefs about multilingual pedagogies and the role of initial training. International Journal of Multilingualism. https://doi.org/10.1080/14790718.2018.1515206

Prenger, R., Poortman, C. L., \& Handelzalts, A. (2017). Factors influencing teachers' professional development in networked professional learning communities. Teaching and Teacher Education, 68(1), 77-90. https://doi.org/10.1016/j.tate.2017.08.014

Redder, A., Schwippert, K., Hasselhorn, M., Forschner, S., Fickermann, D., \& Ehlich, K. (2011). Bilanz und Konzeptualisierung von strukturierter Forschung zu ,Sprachdiagnostik und Sprachförderung“" [Results and conceptualisation of structured research about "language diagonistics and language development"]. Hamburg, Germany: Zentrum zur Unterstützung der wissenschafltichen Begleitung und Forschung schulischer Entwicklungsprozesse [ZUSE].

Reich, H. (2008). Kindertageseinrichtungen als Institutionen sprachlicher Bildung [Early years settings as institutions for language education]. Diskurs Kindheits- und Jugendforschung, 3(3), 249-258.

Sachse, S., Schuler, S., \& Budde-Spengler, N. (2016). Alltagsintegrierte Sprachförderung in Kindertagesstätten. Praktische Implikationen aus dem Projekt MAUS [Integrated language development in early years settings. Practical implications of the project MAUS]. Retrieved from www.ph-heidelberg.de/fileadmin/wp/wp-sachse/Forschungspro-jekte/MAUS/MAUSBroschuere.pdf

Seele, C. (2015). Multilingualism and early education: An ethnography of language practices and processes of institutionalisation in Luxembourgish early childcare settings [Unpublished doctoral dissertation]. University of Luxembourg, Luxembourg.

Simon, S., \& Sachse, S. (2013). Anregung der Sprachentwicklung durch ein Interaktionstraining für Erzieherinnen [Ideas to develop language through interaction training]. Diskurs Kindheits- und Jugendforschung, 8(4), 379-397.

Star, J. R., \& Strickland, S. K. (2008). Learning to observe: Using video to improve preservice mathematics teachers' ability to notice. Journal of Mathematics Teacher Education 11, 107-125. https://doi.org./10.1007/s10857-007-9063-7

Stitzinger, U., \& Lüdtke, U. M. (2014). Mehrsprachigkeit als Potenzial in KiTa-Teams. [Multilingualism as a resource in early years-teams]. (Vol. 2). Osnabrück, Germany: Niedersächsisches Ministerium für Wissenschaft und Kultur.

Thoma, D., \& Tracy, R. (2012). SprachKoPF v06. Instrument zur standardisierten Erhebung der Sprachförderkompetenz pädagogischer Fachkräfte [SprachKoPF v.06. Standardised instrument to measure the practitioners' competence to further language development]. Mannheim, Germany: Mannheimer Zentrum für empirische Mehrsprachigkeitsforschung [MAZEM].

Trodd, L., \& Dickerson, C. (2018). 'I enjoy learning': developing early years practitioners' identities as professionals and as professional learners. Professional Development in Education. https://doi.org/10.1080/19415257.2018.1459788

United Nations. (1989). Convention on the Rights of the Child. Retrieved from: http://www.ohchr.org/EN/ProfessionalInterest/Pages/CRC.aspx

Viernickel, S., Nentwig-Gesemann, I., Nicolai, K., Schwarz, S., \& Zenker, L. (2013). Schlüssel zu guter Bildung, Erziehung und Betreuung - Bildungsaufgaben, Zeitkontingente und strukturelle Rahmenbedingungen in Kindertageseinrichtungen [Key to good education and care - tasks, time and structural conditions in early childhood settings]. Berlin, Germany: Alice-Salomon-Hochschule.

Waters, J., \& Payler, J. (2015). The professional development of early years educators - achieving systematic, sustainable and transformative change. Professional Development in Education, 41(2), 161-168. https://doi.org/10.1080/19415257.2014.1000503

Werner, C. D., Linting, M., Vermeer, H. J., \& van IJzendoorn, M. H. (2016). Do intervention programs in child care promote the quality of caregiver-child interactions? A meta-analysis of randomized controlled trials. Prevention Science, 17, 259-273. https://doi.org/10.1007/s11121-015-0602-7

$\mathrm{Xu}, \mathrm{L}$. (2012). The role of teachers' beliefs in the language teaching-learning process. Theory and Practice in Language Studies, 2(7), 1397-1402. https://doi.org/10.4304/tpls.2.7.1397-1402 


\section{Copyrights}

Copyright for this article is retained by the author(s), with first publication rights granted to the journal.

This is an open-access article distributed under the terms and conditions of the Creative Commons Attribution license (http://creativecommons.org/licenses/by/4.0/). 